Review

\title{
Nanowaste: Another Future Waste, Its Sources, Release Mechanism, and Removal Strategies in the Environment
}

\author{
Zahra Zahra ${ }^{1, *}$, Zunaira Habib ${ }^{2}$, Seungjun Hyun ${ }^{3}$ and Momina Sajid ${ }^{4}$
}

1 Department of Civil and Environmental Engineering, University of California-Irvine, Irvine, CA 92697, USA

2 Institute of Environmental Sciences and Engineering, School of Civil and Environmental Engineering, National University of Sciences and Technology, Islamabad 44000, Pakistan; zunaira.habib@yahoo.com

3 Plamica Labs, Batten Hall, 125 Western Ave, Allston, MA 02163, USA; sjhyun1011@gmail.com

4 Department of Electrical Engineering and Computer Science, 2200 Engineering Hall, University of California, Irvine, CA 92697, USA; msajid@uci.edu

* Correspondence: zahra.nust@gmail.com

check for updates

Citation: Zahra, Z.; Habib, Z.; Hyun, S.; Sajid, M. Nanowaste: Another Future Waste, Its Sources, Release Mechanism, and Removal Strategies in the Environment. Sustainability 2022, 14, 2041. https://doi.org/ $10.3390 /$ su14042041

Academic Editor: Agostina Chiavola

Received: 1 January 2022

Accepted: 7 February 2022

Published: 11 February 2022

Publisher's Note: MDPI stays neutral with regard to jurisdictional claims in published maps and institutional affiliations.

Copyright: (C) 2022 by the authors. Licensee MDPI, Basel, Switzerland. This article is an open access article distributed under the terms and conditions of the Creative Commons Attribution (CC BY) license (https:// creativecommons.org/licenses/by/ $4.0 /)$.

\begin{abstract}
Nanowaste is defined as waste derived from materials with at least one dimension in the 1-100 nm range. The nanomaterials containing products are considered as "nanoproducts" and they can lead to the development of nanomaterial-containing waste, also termed as "nanowaste". The increased production and consumption of these engineered nanomaterials (ENMs) and nanoproducts that generate enormous amounts of nanowaste have raised serious concerns about their fate, behavior, and ultimate disposal in the environment. It is of the utmost importance that nanowaste is disposed of in an appropriate manner to avoid an adverse impact on human health and the environment. The unique properties of ENMs, combined with an inadequate understanding of appropriate treatment techniques for many forms of nanowaste, makes nanowaste disposal a complex task. Presently, there is a lack of available information on the optimized standards for identifying, monitoring, and managing nanowaste. Therefore, this review highlights concerns about nanowaste as future waste that need to be addressed. The review focuses on ENMs waste (in the form of NP, nanotubes, nanowires, and quantum dots) generated from the manufacture of a wide variety of nanoproducts that end up as nanowaste and adversely affect the environment. Furthermore, the review considers different types of ENMs in waste streams and environmental compartments (i.e., soil, water, and air). Detailed studies are still required to identify data gaps and implement strategies to remove and control this future waste.
\end{abstract}

Keywords: nanowaste; future waste; engineered nanomaterials; release mechanism; environment; removal strategies

\section{Introduction}

The massive increase in global production and consumption of nanomaterials has raised concerns about new forms of waste, known as "nanowaste". The term nanowaste refers to engineered nanomaterials (ENMs) [1]. Nanotechnology entails the manipulation of materials at a nanoscale that are called nanomaterials. These nanomaterials are used in a wide range of applications, including displays, LED lightning, electronic devices, biomedical devices, solar panels, water filtration, and consumer products. As part of our daily use of these products, nanomaterials along with conventional waste enter the waste streams without an understanding of their impact on human health and the environment [2]. Furthermore, they can also occur in the form of organic or inorganic substances (i.e., carbon, metals, and metal oxides) or in combinations to form complex substances [3].

There is a need to implement a framework for the effective monitoring and disposal of nanomaterial-containing waste. In waste management, the first step is the quantification of waste produced. Nanomaterials undergo several modifications throughout their stay in the environment and other systems, depending on their properties, making nanowaste 
quantification more challenging [4]. ENMs act as a "Trojan horse", a term mostly used to describe how an ENM carries hazardous contaminants and disperses them in the ecosystem [5]. In this review, we discuss nanowaste, its source and release mechanism in different environmental compartments, its ecological impact, and control strategies to manage and remove this waste.

Presently, there are no data reported on the amount of nanowaste generated from nano-related processes, nor any classification of the product left post consumption from the industrial sector (during development and manufacturing processes). Because nanomaterials are disposed of directly into the environment resulting in "nanopollution", they are not considered as nanowaste. For example, after washing or rinsing, cosmetics and textiles containing nanomaterials (e.g., $\mathrm{TiO}_{2}, \mathrm{ZnO}$, and $\mathrm{Ag} \mathrm{NP}$ ) can enter wastewater streams [6-9]. Therefore, nanowaste (or nanopollutants) needs to be collected separately from the product. Among nanomaterials, quantum dots (QDs) are semiconductor nanocrystals that have been created to possess unique fluorescence, quantum confinement, and quantum yield capabilities, making them useful in a wide variety of applications such as displays and lighting technologies. Increased production and consumption of QDs has increased the likelihood of these nanomaterials entering the environment at various stages of their life cycle. Recently, a review reported the major types and applications of QDs, along with their possible environmental exposures and harmful effects on organisms. In the case of most applications, the release of QDs into the environment is predicted to occur mostly during their synthesis and end-product production stage [10].

Nanowaste can be generated in different categories (shown in Figure 1) from different types of nanomaterials used in different forms or incorporated in different products named as nanoproducts [8,9]. Examples include metal waste/scrap, batteries, solar cells, tires, paper, cardboard, plastics, textiles, leather, electronics, and medical devices [1].

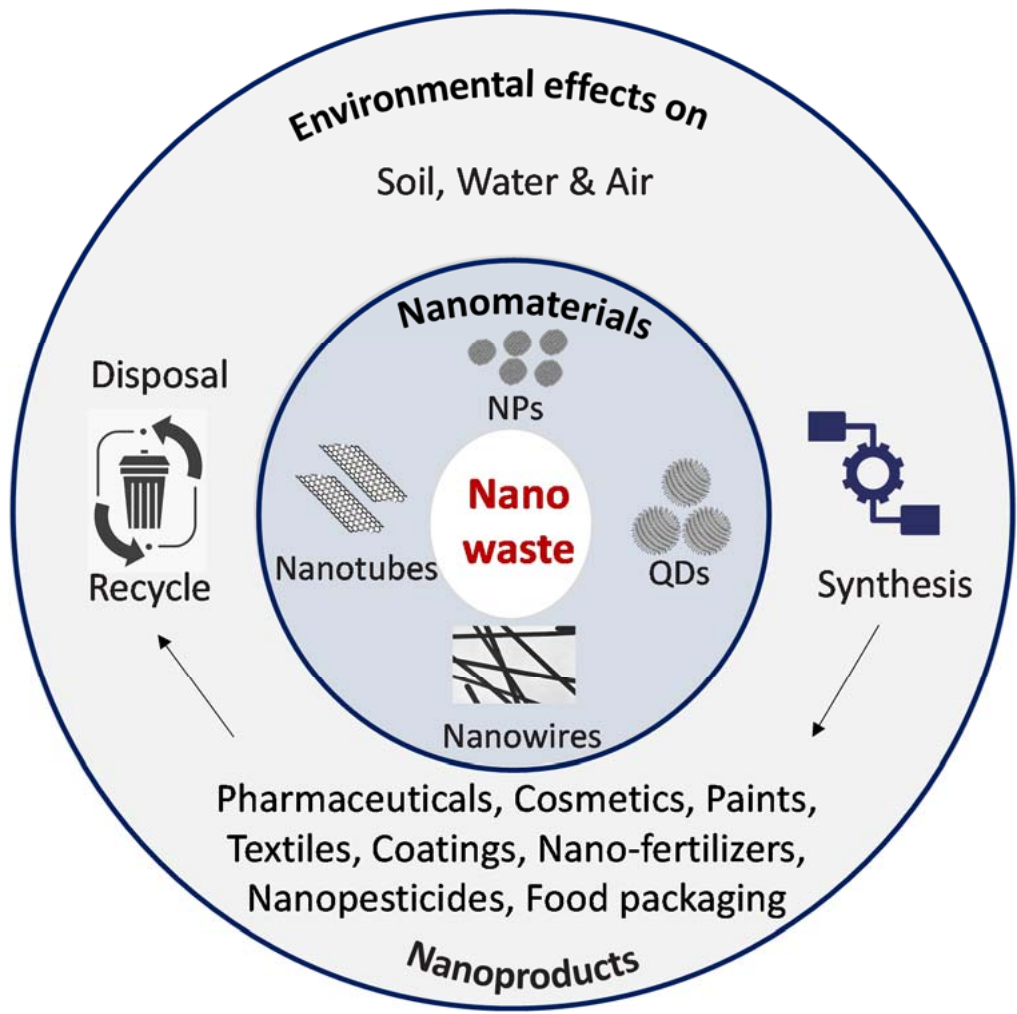

Figure 1. Schematic illustration of nanomaterials (in the form of NP, quantum dots, nanowires, and nanotubes), from their synthesis to the manufacture of a wide variety of nanoproducts that end up as nanowaste and adversely affect the environment [10]. 


\section{Sources of Nanowaste (Point and Non-Point Sources)}

The rapid increase of nanowaste in nature is the result of higher manufacturing and utilization, and this has brought the issue into the consideration of relevant parties. Natural or anthropogenic tasks are the two major means of contamination of the environment due to nanowaste, with the latter source being either intended or unintended. This intended or unintended contamination of the environment is enabled by introducing nanowaste into the soil, air, and water. Nanowaste contamination can occur in the environment through raw materials' manufacturing processes, nanowaste management, nano-enabled products, and the use of such products [11]. Once NP contaminate the environment, they can spread out to various areas, either as aerosols, by floating in water, or by depositing themselves in soil sediments. The fact that NP are so small makes them highly susceptible to spread in the environment in any form, making them even more dangerous and harmful. Moreover, due to their highly reactive nature, they can chemically react with other secondary pollutants, resulting in new pollutants that are not only harmful but even more difficult to remove from the environment [12]. The situation worsens when environmental contamination due to NP in the soil and irrigation water results in their entry into crops and thus their eventual entry into the food chain [13]. Nanowaste sources can be divided into two main categories: point sources and non-point sources.

\subsection{Point Sources}

Point sources result in the direct release of nanowaste into nature. Examples of point sources include storage and manufacturing units, research and experimental labs, wastewater treatment factories, and the discarding of consumption goods made from nanomaterials [14]. Such nanowaste from factories enters water bodies and soil as sewage and sludge. For example, the use of silver (Ag) NP is common in household items, such as cosmetics and personal care products, food, and drinks, that produce a huge quantity of nanowaste in home sewage waste, resulting in a detrimental effect on the environment [15]. Among household products, cosmetics and personal care products are more dangerous as they contribute nearly $50 \%$ of nanoproducts in the world market [16]. In recent years, there has been a further increase in the use of nanomaterials in such industries, more so since they can be used widely due to their diverse properties, such as their ability to reflect UV light while remaining transparent (e.g., titanium oxide), anti-aging skin effects (e.g., gold particles and nanosomes), antibacterial effects (e.g., nanosilver) and antioxidant properties that are even greater than Vitamin E (e.g., C60 fullerene). This high incorporation of nanomaterials into household products results in a higher release of nanowaste into the sewage system through showering and washing, resulting in the pollution of water bodies and eventually increased environmental contamination. Moreover, due to the highly reactive nature of nanomaterials, new compounds materialize leading to further difficulty in detecting nanowaste and ensuring its appropriate disposal. In many cases, such compounds can go through various treatment processes undetected and untreated [12].

\subsection{Non-Point Sources}

Non-point sources include nanowaste generated from the damage or deterioration of NP-containing products, paints, cosmetics, and cleaning products. Nanomaterials are broadly used in many applications, however, amongst them all, paints and pigments contribute a lot of the nanowaste release because they can easily enter water resources and soil. For example, $\mathrm{TiO}_{2} \mathrm{NP}$ have been frequently used in paints due to their photocatalytic, antimicrobial, and self-cleaning attributes. However, when paint coatings face environmental conditions over long periods of time, these NP can be released as nanowaste into the environment [17]. Moreover, an increased percentage of nanomaterials have also been used in electronics and optics, and they generate an enormous amount of nanowaste that likely enters the environment through dumping grounds and landfill. The use of cosmetics made from nanomaterials results in the environment being exposed to NP which end up polluting the soil as well as water bodies. The leaching rate of various types of nanowaste depends 
on that product's manufacturing process, and this leaching rate affects the level of pollution that ends up spreading in the soil and water bodies [18]. According to estimates, $95 \%$ of nanowaste ends up reaching the wastewater treatment plants (WWTP) due to wearing off during early use or disposal, leading to a detrimental impact on nature [19]. Nanotechnology has broadened its applications towards decontaminating the environment and the soil, especially organic pollutants that include organic solvents, pesticides, polychlorinated biphenyls, polycyclic aromatic hydrocarbons, and medicinal and self-care items [20]. The intended application of using NP to decontaminate the environment can result in a buildup of nanowaste in the soil, resulting in further soil pollution. The use of nanoparticles in agriculture and their widespread application not only results in soil pollution as highlighted, but also leads to the contamination of water bodies due to contaminated run-off water. Sustainable agriculture has found a new use for nanofertilizers; they are used to enrich the soil with the required nutrients, especially $\mathrm{Cy}, \mathrm{Fe}, \mathrm{Mn}, \mathrm{Mo}$, and $\mathrm{ZnO}$, resulting in high-yield products [21]. In addition, progressive innovations and applications, such as nanosensors and smart delivery systems, are being used to regulate pests, pathogens, and enhance nutrient supply systems [22]. When it comes to atmospheric contamination by nanowaste, combustion, end-user aerosols, automobile exhaust fumes, and smoke and ashy pollution from industries are significant sources [23]. Once in the atmosphere, this waste can precipitate and end up in the soil and water bodies. Nanowaste can leach down and percolate into the groundwater through a contaminated soil medium [23]. Furthermore, such NP affect the soil's microbial diversity and plant performance, thereby having a detrimental impact for humans [1,24-26].

\section{Release Mechanism in Different Environmental Compartments and Exposure Pathways}

The release of nanowaste from its source can occur via a physical container or a product in which nanomaterials are used or embedded. These ENMs can enter the environment as nanowaste at any stage of the nanomaterial's life process. During manufacturing, nanomaterials can enter the environment in different forms; during utilization, nanomaterials can be released due to wear and tear (e.g., abrasion on painted walls); and in the disposal or end-of-life phase, they can also be released (e.g., landfill, incineration, or recycling) [27].

Once the life cycle of nanomaterials is completed, they may be deposited in last compartments (either natural or man-made), for example, dumping grounds or landfill. If the nanoproduct is used again or recycled, the nanomaterial ends up being a part of another manufacturing process [28]. The highest probability for unrestricted nanomaterial release is during their utilization phase (Figure 2) for most nano-applications. Practically, nanomaterials have a greater chance of being released as part of the materials they are incorporated in, or the materials they are transformed into, rather than as single units [29]. Thus, evaluating the release of nanomaterials in their single form is as equally important as them being a part of various materials or transformed types. It is estimated that, on average, $63-91 \%$ of the 10 most produced ENMs are disposed of in landfill, while $0.4-7 \%$ of total global production is released into water bodies. Air emissions contribute the lowest flow, being less than $1.5 \%$ of ENM production into the atmosphere [18].

As shown in Figure 2, there are two steps through which ENMs contaminate the environment. The first step is shown by dark blue arrows depicting their release during ENM product handling, while the second step is shown by light blue arrows depicting the eventual release of nanowaste into the environment. The dashed boxes depict the sectors that delay the eventual contamination into the environment. Note that recycling is not connected back to manufacturing at the start of the cycle, since the ENM will either be thrown away (dumping grounds or burned) or incorporated into other products (e.g., plastics) that are used to manufacture other products, rather than into ENM or nanoapplications [28]. 


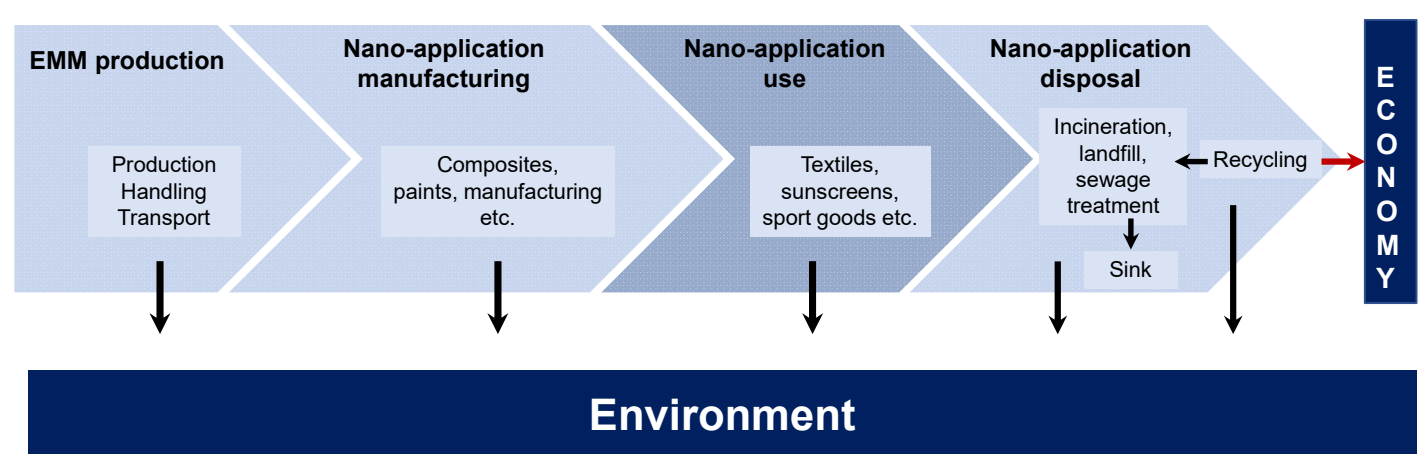

Figure 2. The life cycle of ENMs and their release into the environment from the manufacturing to disposal phase [28]

\subsection{Potential Release during the Production Phase}

ENMs can be released into technical or environmental compartments [30-34]. Examples of technical compartments are manufacturing areas, storehouses, conveyance vehicles, markets, homes, workplaces, swimming pools, garbage disposal areas, and any place where ENMs and nanoproducts are utilized, kept, or processed. Environmental compartments include soil, water, and air. However, the release of ENMs during the production phase depends on the process employed. Higher concentrations of smaller-size NP are more likely to be released during high-energy processes including spraying and synthesis. Conversely, moderate or trivial releases of relatively massive agglomerates occur during low-energy processes such as cleaning, handling, and the packing of ENMs in industries [35]. ENMs can contaminate the environment through intrinsic and extrinsic factors. Intrinsic factors are not only associated with the built-in properties of ENMs but also with the properties of nano-products in terms of the amount released into the environment [36]. However, extrinsic factors are linked to the systems where ENMs are processed and utilized, including management, consumer choices, technological aspects, and economic development, etc. Conclusively, in the production or manufacturing stage, the release of ENMs depends on the production method and employed technology, plus the environmental policies followed by companies as well as the filtration technique employed to evade their release into the environment [27]. During the handling phase, the release of ENMs depends on the method of their incorporation into products (i.e., suspension in solids or liquids, surface-bound, or aerosols) and their usage by consumers [37]. System variables that affect their release during manufacturing involve technological factors, as well as economic development such as market penetration, expansion, and advanced innovation of nano-applications.

\subsection{Release Behavior during the Consumption Phase}

Environmental contamination by ENMs can be either direct (directly into nature) or indirect (first into a compartment and then into nature). Technical facilities may reduce the ENM contamination of the environment by applying filtration methods [27]. For example, a swimmer wearing a sunscreen will result in the release of nano- $\mathrm{TiO}_{2}$ into the water and ultimately the sewage, thus causing an indirect transfer. On the other hand, if the swimmer swims in a river or lake, this causes a direct transfer. ENM contamination in the environment can be intentional or unintentional. For example, the planned transfer of ENMs into nature to restore water bodies (e.g., nano-scale zerovalent iron is used for water treatment) is an intentional release [38]. The unintentional release of ENMs can occur due to the wear and tear of nanoproducts during their handling [39] or due to their use in applications including aerosols that result in $100 \%$ release into the atmospheric environment.

The release of composite nanoobjects, agglomerates, and aggregates (NOAAs) from consumer-used materials have been reported in the literature, while only a limited number of studies reported the release of free ENMs. For example, a study reported that free nano$\mathrm{TiO}_{2}$ particles were released from nano- $\mathrm{TiO}_{2}$-containing paints in minute form. However, most of these were entrapped by the organic paint binder, resulting in small pieces of 
paint matrix having nano- $\mathrm{TiO}_{2}$ [40]. Another study also reported that the release of free $\mathrm{TiO}_{2}$ can occur due to the wear and tear of photocatalytic nano-coatings used in building materials [17]. It has been reported that NOAAs enter the soil or groundwater due to wear and tear, or leaching, while they can be released indirectly into the environment through atmospheric deposition. Either directly or indirectly, all NOAAs were released either in the soil or water bodies where they could have detrimental effects on human health and the environment [41].

\subsection{Potential Release during the End-of-Life Phase}

The employed technology and waste handling protocols determine the release of ENMs during disposal $[30,42-44]$. The implemented policies affect the techniques employed for nano-products such as landfill, incineration, and recycling, whereas the characteristics of the processes are defined by available technology [28]. Biodegradable nanowaste such as graphene nanoparticles (GNPs) and multi-wall carbon nanotubes (MWCNTs) can be easily leached out into the environment through weathering and partial degradation if disposed of into landfill. The compost prepared from this type of nanowaste must have a huge number of GNPs, as well as bulk graphene and carbon nanotubes. Once this compost is used for soil improvement, it might be a potential source of ENM into the food chain by making its way from soil to groundwater [45].

Waste management strategy in terms of converting waste into energy production (thermal valorization) has recently been studied; however, the risk of thermoplastic emissions into the environment through incineration must be investigated in this scenario [44]. Furthermore, in underdeveloped areas, any type of environmental hazards (burning or accidental fire) in landfill might be a potential risk to humans and environment because of this huge explosion. In particular, for temperatures above $600^{\circ} \mathrm{C}$, carbon nanotubes (CNTs) and graphene are combustible and thus can be converted into $\mathrm{CO} / \mathrm{CO}_{2}$ during this process [44]. However, the residue (ash) formation containing unburned CNTs due to the incineration of polymer composites with CNTs has been reported in very few studies [46-48]. Furthermore, the CNTs might be released during the combustion gas phase [44].

During incineration or fire, airborne particles from nanomaterials can be released. A study reported that GNPs and MWCNTs can either be released into the air or remain in burned residue during incineration. The complete biodegradation of GNPs/MWCNTs results in large amounts of GNP and MWCNT particles being released. This issue has raised serious concerns about environmental and human health risks related to the composting of nanoproducts waste since such NP become a part of the soil. Incineration of nanowaste at $500{ }^{\circ} \mathrm{C}$ has the risk of "unacceptable risk/hazard" level due to the release of GNPs and MWCNTs, but this risk drops to "high" if the temperature increases to $850^{\circ} \mathrm{C}$. Specifically, the incineration of nanoproduct waste in open areas such as dumping grounds (a common practice in underdeveloped areas) leads to a "high" risk. Thus, these procedures need to be carefully monitored and regulated because they can have extremely detrimental impacts on humans and the environment. Accidental fires can result in an "acceptable" risk, but they do have negative effects, therefore, safety actions must be implemented [45].

\section{Environmental Impacts of Nanowaste on Different Environmental Compartments}

\subsection{Potential Impacts on Soil}

Based upon modeling studies, the majority of ENM contamination occurs in the soil environment compared to water or air $[49,50]$. ENMs are now considered as emerging pollutants due to their potential toxicity hazards and impacts on the environment [51-54]. There is a need to develop rules and regulations based upon ENM characteristics, behavior, and their potential risks to human health and the environment [55]. Studies on the risk evaluation of ENM (e.g., $\mathrm{ZnO}, \mathrm{Ag}$, and $\mathrm{Cu}$ ) at various levels in the food chain have highlighted that those higher concentrations are harmful to the environment and organisms including bacteria, algae, fish, crustaceans, and nematodes [56-58], as shown in Figure 3. 


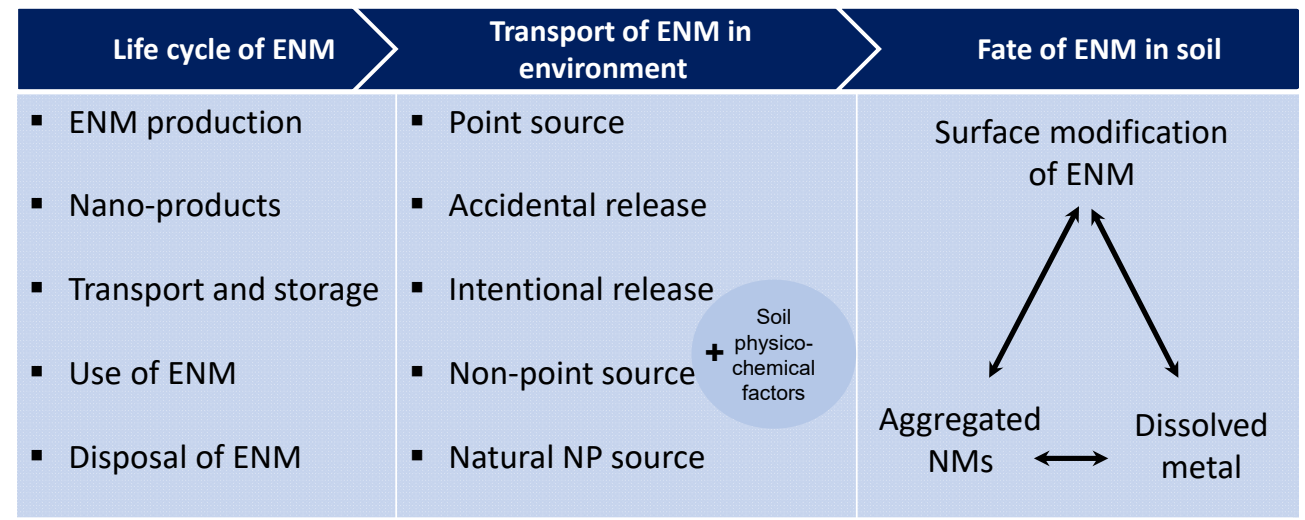

Figure 3. Behavior and characterization of nanomaterials and their fate in soils as nanowaste [58].

Nanowaste results in NP which are increasingly entering the natural habitat, and they may combine either with the soil, water, or air in various processes [59]. Moreover, NP that became part of one compartment of nature may also become part of other compartments; for example, the NP in the air may also end up in water bodies or the soil, thereby polluting them. This mass collection of nanowaste and its by-products can interact with plants and animals, thereby having extremely detrimental and toxic impacts on them. Notably, human beings may face various health issues if they encounter soil, water, or air contaminated with nanowaste, or even food contaminated with nanowaste. Thus, highly hazardous and reactive nanowaste needs to be managed either by nullifying the hazard or by recycling and transforming it into nontoxic variants [59].

Another category of nano-enabled hazardous products is agro-veterinary chemicals. Although their main impact is on soil and water bodies, agro-veterinary chemicals can also be released into the atmosphere [60]. Accidental discharge of nanowaste from industries, including but not limited to fire, loss of containment, etc., also results in the release of ENMs into the natural habitat. For example, there are reports of, on average, $0.7 \%$ to $1.6 \%$ of ENMs being released from various manufacturing areas, with $6 \%$ of this estimated to be released into the air [61]. However, a report on fine particles mentioned that in comparison to the carbon-containing compounds released during combustion, these procedures were not estimated to result in a significant increase of NP atmospheric concentration [62]. Environmental factors such as atmospheric temperature, relative humidity, and turbulence govern the size distribution and particle number concentration of ENMs if they are discharged into the atmosphere. Furthermore, in the atmosphere, changes in ENMs are mediated by photochemically generated processes, which are primarily driven by free radicals and UV radiation [63].

Nanomaterials used in a wide range of applications undergo several disposal procedures, including incineration, accidental fires, and biodegradation. Nanowaste containing polymers that undergo biodegradation is especially dangerous. Although incineration can result in biodegradable plastics converting into beneficial components in the soil that result in soil improvement, care should be taken when dealing with local burning of such nanowaste because environmental hazards due to NP release in the soil and air are obvious [64].

\subsection{Potential Impacts on Water}

ENMs have been extensively used in every domain of life, from an ordinary household item to an advanced medical technology, due to their unique and multidisciplinary properties. However, the environmental risk associated with the use of ENMs begins right after their production and continues until the completion of their life cycle in respective water bodies. The extent of toxicity associated with these ENMs depends on their shape, size, aggregation state, crystallinity, catalytic activity, ability to generate reactive oxygen species (ROS), and their band gap energy [65]. Upon exposure to the environment, these 
nanomaterials deposit on porous or solid surfaces and make their route in aqueous media and cause hazardous threats to aquatic species [66]. Furthermore, the transformation of nanomaterials as being reactive material with other chemical species might be contributing to their toxicological effects. Regardless of progressive aspects, their migration in water bodies is a matter of great concern.

The potential toxicity linked to the production, application, and disposal of these ENMs have gain considerable attention in the research community [67]. Among the other ENMs, $\mathrm{TiO}_{2}$ and $\mathrm{SiO}_{2}$ are widely used nanomaterials and hence are produced in large volumes; the approximate annual production is 5500 and 3000 tons of $\mathrm{SiO}_{2}$ and $\mathrm{TiO}_{2}$, respectively [68]. Upon completion of their life cycle, these ENMs accumulate in water bodies and remain there for several years due to their insoluble nature [69]. ENMs present in cosmetic products are the crucial source of nanowaste in water, entering through washing, bathing, showering, and swimming processes. From consumer products, ENMs enter the sewage water through the routes shown in Figure 4: (i) directly during manufacturing of raw materials as well as consumer products; (ii) during usage; and (iii) waste handling [9]. From industrial processes, the mixing of these ENMs to sewage water takes place either through wastewater treatment plants or in the form of leachate from landfill [70]. Mahlalela et al. [71] stated that only $10 \%$ of NPs were added into treated effluent while $90 \%$ were retained in sludge, which would be disposed of in landfill and become part of underground water in the form of leachate.

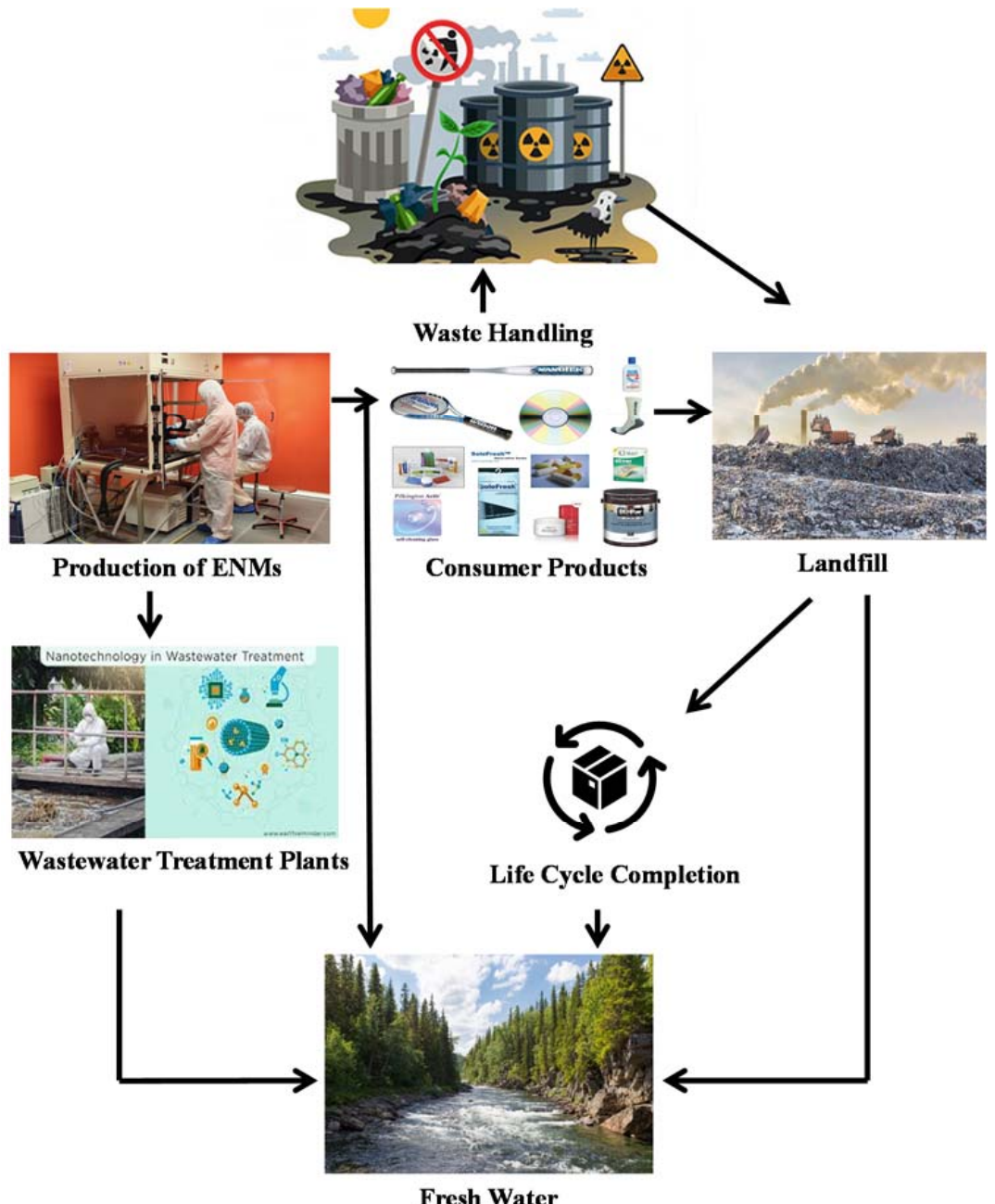

Figure 4. Entry routes of ENM into freshwater sources. 
Although ENM have been observed in various consumer products, the amount detected in municipal wastewater varies seasonally depending on the use of products according to climate and weather conditions. For example, sunscreen use is higher in summer, whereas moisturizers and body lotions containing $\mathrm{ZnO}$ and $\mathrm{TiO}_{2}$ are frequently used in winter. In addition, surface run-off of ENMs from automobiles, buildings, roofs, and household paints might be enhanced due to a humid environment [72]. However, the massive source of $\mathrm{TiO}_{2}$, approximately $85 \%$ of total release in surface water, is coming from landfill due to the soil being treated with sludge [73]. Likewise, the dumping of electronics, cosmetics, and medicines allows $\mathrm{ZnO}$ to accumulate in soil and landfill that ultimately becomes a part of water bodies through leaching [74]. The other ENMs, including carbon nanotubes (CNTs) and silver $(\mathrm{Ag})$, enter the surface water during the manufacturing process and accumulate in landfill and biofilm reactors [75,76]. Besides this, a significant amount of Ag NM embedded in fabrics has also been detected in wastewater streams during laundry [72].

The rapid increase in the production and usage of ENMs has generated a gap between the launching and appropriate final disposal of nanomaterials into the environment. That is why research considering the impact of ENMs on the human and natural environments is ambiguous. The primary source of ENMs in numerous water bodies is industrial effluent treatment plants. However, a significant gap exists about the mobility, fate, and transformation of ENMs in a complex water system. The release of ENMs into natural water bodies not only poses serious threats to human but also to aquatic biota [77]. ENM with concentrations in $\mu \mathrm{g} / \mathrm{L}$ and $\mathrm{ng} / \mathrm{L}$ have already been detected in drinking water sources, even at household level [78]. Upon entering the food chain, these ENMs can cause serious threats to human health [79]. Despite limited information, the toxic effects of cationic NP are already understood. These NP are biodegradable and can easily penetrate into the cells and tissues, resulting in organ dysfunction, tissue damage, and membrane destabilization. However, the extent of toxicity depends on the amount and exposure time of ENM, as well as their entry route into body [80].

ENMs make their way directly into freshwater sources and have acute as well as chronic toxicity to aquatic biota. A study reported the acute (72 h) and chronic (21 days) toxicity of $\mathrm{TiO}_{2} \mathrm{NPs}$ on Daphnia Magna, present in freshwater bodies. The values of LC50 and EC50 were $2.02 \mathrm{mg} / \mathrm{L}$ and $1.62 \mathrm{mg} / \mathrm{L}$, respectively. After an exposure of $48 \mathrm{~h}$, acute toxicity was trivial. However, after 21 days, a high mortality rate, reproductive defects, and growth retardation were detected even at a concentration of $0.1 \mathrm{mg} / \mathrm{L}$. The extent of toxicity depends on the size of $\mathrm{TiO}_{2} \mathrm{NPs}$; smaller particle sizes activate larger number of intracellular reactive oxygen species (ROS) in Daphnia Magna [81]. Moreover, these ENMs have toxic impacts on various species of fish. Ag NPs inhibited bacterial growth on Danio rerio's mucus with concentrations of 25, 50, and $100 \mu \mathrm{g} / \mathrm{L}$ [82]. Fullerenes (nC60) accumulation in the liver of Cyprinus carpio over a 10-day period resulted in oxidative stress and a high cholesterol level [83]. All living cells have the capability to transform the toxicity of ENMs to aquatic flora and algae [5]. For example, the exposure of ZnO NPs to Hydrilla verticillata (aquatic macrophyte) and Dunaliella tertiolecta (marine algae) resulted into oxidative stress and DNA damage, respectively [84,85]. Table 1 shows other examples of potential toxicity on the growth of aquatic biota. These ENMs can also act as vectors to carry other harmful pollutants present in soil and water and accumulate in the body of aquatic microorganisms as a particle-contaminant complex [63]. 
Table 1. Potential impacts of nanowaste in aquatic ecosystem.

\begin{tabular}{|c|c|c|c|}
\hline Type of Nanowaste & Conditions & Toxic Impacts & Reference \\
\hline CdS NPs & $\begin{array}{l}\text { Freshwater fish (Channa punctatus) } \\
\text { exposed to } 50 \mu \mathrm{g} / \mathrm{L} \text { for } 15 \text { and } \\
30 \text { days }\end{array}$ & $\begin{array}{l}\text { Mucous cells loss and damage to gill } \\
\text { epithelium was observed after } \\
15 \text { days, whereas, substantial } \\
\text { deterioration observed after } 30 \text { days. }\end{array}$ & [86] \\
\hline ZnO NPs & $\begin{array}{l}\text { Freshwater microalgae (Coelastrella } \\
\text { terrestris) exposed to } 0.1,0.5 \text {, and } \\
1 \mathrm{mg} / \mathrm{L} \text { for } 40 \text { days }\end{array}$ & $\begin{array}{l}\text { Cytoplasm shrinkage and damage to } \\
\text { cell wall and cell organelle was } \\
\text { observed. The extent of the toxicity } \\
\text { was dependent on exposure time and } \\
\text { dose concentration. }\end{array}$ & [87] \\
\hline $\mathrm{TiO}_{2} \mathrm{NPs}$ & $\begin{array}{l}\text { Freshwater cyanobacteria (Microcystis } \\
\text { aeruginosa) exposed to } \mathrm{TiO}_{2} \mathrm{NPs} \text { at } \\
\text { concentrations of } 0.1,1,10,50 \text {, and } \\
100 \mathrm{mg} / \mathrm{L} \text {; samples were collected at } \\
\text { various intervals from } 0-96 \mathrm{~h}\end{array}$ & $\begin{array}{l}\text { Hormesis effects were observed at } \\
\text { lower concentrations }(0.1 \text { and } \\
10 \mathrm{mg} / \mathrm{L}), \text { whereas higher } \\
\text { concentration ( } 50 \text { and } 100 \mathrm{mg} / \mathrm{L}) \\
\text { resulted in growth inhibition due to } \\
\text { shading effect. }\end{array}$ & [88] \\
\hline $\mathrm{TiO}_{2} \mathrm{NPs}$ & $\begin{array}{l}\text { Marine microalgae (Chlorella vulgaris) } \\
\text { exposed to } \mathrm{TiO}_{2} \mathrm{NPs} \text { at } \\
\text { concentrations of } 1,5,10,50 \text {, and } \\
100 \mathrm{mg} / \mathrm{L} \text { in acidified water; samples } \\
\text { were collected at } 24,48,72 \text {, and } 96 \mathrm{~h}\end{array}$ & $\begin{array}{l}\text { Growth inhibition was enhanced due } \\
\text { to ocean acidification, while there } \\
\text { was oxidative damage to algal cells } \\
\text { due to the synergistic effect of } \mathrm{TiO}_{2} \\
\text { NPs and pH. }\end{array}$ & [89] \\
\hline $\mathrm{TiO}_{2} \mathrm{NPs}$ & $\begin{array}{l}\text { 0, 40, } 100,200,400, \text { and } 1000 \mathrm{mg} / \mathrm{L} \text { of } \\
\mathrm{TiO}_{2} \mathrm{NPs} \text { exposed to marine } \\
\text { microalgae (Isochrysis galbana); } \\
\text { samples were collected at } 24,48,72, \\
\text { and } 96 \mathrm{~h}\end{array}$ & $\begin{array}{l}\text { No pronounced impacts were } \\
\text { observed on reproducibility and the } \\
\text { size of algal cells. However, the } \\
\text { efficiency of algal chlorophyll } \\
\text { deteriorated and resulted in lower } \\
\text { photosynthesis. }\end{array}$ & [90] \\
\hline $\mathrm{TiO}_{2}$ NPs & $\begin{array}{c}\text { Bioaccumulation of NPs }(0.05,0.1,1, \\
5 \text {, and } 10 \mathrm{mg} / \mathrm{L}) \text { in aquatic plant } \\
\text { (Spirodela polyrrhiza) was detected for } \\
20 \text { days }\end{array}$ & $\begin{array}{l}\text { Significant reduction in enzymatic } \\
\text { activity, growth, and photosynthetic } \\
\text { pigmentation was observed by } \\
\text { increasing concentration. }\end{array}$ & [91] \\
\hline ENMs from Graphene family & $\begin{array}{c}\text { Freshwater algae (Chlorella } \\
\text { pyrenoidosa) exposed to } 37.3,34.0 \text {, and } \\
62.2 \mathrm{mg} / \mathrm{L} \text { of } \mathrm{GO}, \mathrm{rGO} \text {, and } \mathrm{MG}, \\
\text { respectively, for } 96 \mathrm{~h}\end{array}$ & $\begin{array}{l}\text { A measured } 16.4 \% \text { of growth } \\
\text { inhibition due to shading effect was } \\
\text { observed for GO due to its } \\
\text { dispersive nature. }\end{array}$ & [92] \\
\hline $\mathrm{ZnO}$ NPs & $\begin{array}{l}\text { Embryo of zebrafish (Danio rerio) } \\
\text { exposed to concentrations of } 10,30 \\
60,90, \text { or } 120 \mathrm{mg} / \mathrm{L} \text { for } 96 \mathrm{~h}\end{array}$ & $\begin{array}{c}\text { Heartbeat increased and the } \\
\text { capability to hatch embryo decreased. }\end{array}$ & [93] \\
\hline $\mathrm{Ag} \mathrm{NPs}$ and $\mathrm{AgNO}_{3}$ & $\begin{array}{l}\text { Rainbow trout (Oncorhynchus mykiss) } \\
\text { exposed to } \mathrm{Ag} \mathrm{NPs}(40 \mu \mathrm{g} / \mathrm{L}) \text { and } \\
\mathrm{AgNO}_{3}(4 \mu \mathrm{g} / \mathrm{L}) \text { for } 96 \mathrm{~h}\end{array}$ & $\begin{array}{l}\text { Both forms of silver accumulated in } \\
\text { the liver, and induced inflammation } \\
\text { (enhanced cyclooxygenase activity) } \\
\text { and immunosuppression. }\end{array}$ & [94] \\
\hline Ag NPs & $\begin{array}{l}\text { River fish (Labeo rohita) exposed to } \\
\text { concentrations of } 100,200,400 \text {, and } \\
800 \mu \mathrm{g} / \mathrm{L} \text { for } 7 \text { days }\end{array}$ & $\begin{array}{l}\text { Toxicity in terms of cellular response } \\
\text { and DNA damage was observed at } \\
400 \text { and } 800 \mu \mathrm{g} / \mathrm{L} \text {. Time and } \\
\text { dose-dependent relationship was } \\
\text { observed in hepatocytes and vacuolar } \\
\text { degeneration on liver examination. }\end{array}$ & [95] \\
\hline $\mathrm{Zn} \mathrm{NPs}$ and $\mathrm{ZnCl}_{2}$ & $\begin{array}{l}\text { Larval zebrafish (Danio rerio) exposed } \\
\text { to } \mathrm{Zn} \text { NPs }(0.2-6 \mathrm{mg} / \mathrm{L}) \text { and } \mathrm{ZnCl}_{2} \\
(0.1-3 \mathrm{mg} / \mathrm{L}) \text { for } 96 \mathrm{~h}\end{array}$ & $\begin{array}{l}\text { Higher DNA damage was observed } \\
\text { due to } \mathrm{ZnCl}_{2} \text {, Toxicity in various } \\
\text { stress-related genes ( } p 53, \text { rad51, mt2) } \\
\text { was analyzed and substantial } \\
\text { induction in mt } 2 \text { was examined at } \\
\text { highest concentrations ( } 3 \text { and } \\
6 \mathrm{mg} / \mathrm{L} \text { ) due to release of } \mathrm{Zn}(\mathrm{II}) .\end{array}$ & [96] \\
\hline $\mathrm{TiO}_{2} \mathrm{NPs}$ & $\begin{array}{c}\text { Marine fish (Rachinotus carolinus) } \\
\text { injected with } 1.5 \mu \mathrm{g} \text { and } 3.0 \mu \mathrm{g} / \mathrm{g} \text { of } \\
\text { NPs for } 24,48 \text {, and } 72 \mathrm{~h}\end{array}$ & $\begin{array}{l}\text { Uptake of NPs in various organs } \\
\text { resulted in cytotoxic and genotoxic } \\
\text { impacts in terms of DNA damage, } \\
\text { and erythrocyte and micronucleus } \\
\text { abnormalities. }\end{array}$ & [97] \\
\hline
\end{tabular}


Table 1. Cont.

\begin{tabular}{|c|c|c|c|}
\hline Type of Nanowaste & Conditions & Toxic Impacts & Reference \\
\hline $\mathrm{Au}$ NPs & $\begin{array}{l}\text { Zebrafish (Danio rerio) exposed to } 16 \\
\text { and } 55 \mu \mathrm{g} / \mathrm{g} \text { of NPs through } \\
\text { sediments for } 20 \text { days }\end{array}$ & $\begin{array}{l}\text { Alteration in gene expression was } \\
\text { observed in terms of detoxification, } \\
\text { mitochondrial metabolism, DNA } \\
\text { repair, and oxidative stress. }\end{array}$ & [98] \\
\hline Citrate- $\mathrm{TiO}_{2} \mathrm{NPs}$ & $\begin{array}{c}\text { Zebrafish embryo exposed to } \\
0-1000 \mu \mathrm{g} / \mathrm{mL} \text { NPs of size } 6,12, \text { and } \\
15 \mathrm{~nm} \text { under sunlight and } \\
\text { dark conditions }\end{array}$ & $\begin{array}{l}\text { Various defects, including opaque } \\
\text { yolk, yolk-sac, and pericardial edema } \\
\text { and craniofacial malformation, were } \\
\text { detected for } 6 \mathrm{~nm}\left(120 \mathrm{~h} \mathrm{LC}_{50} \text { of }\right. \\
\left.23.4 \mathrm{mg} \mathrm{L}^{-1}\right) \text { citrate- } \mathrm{TiO}_{2} \mathrm{NPs}\end{array}$ & [99] \\
\hline CNTs & $\begin{array}{l}\text { Zebrafish (Danio rerio) exposed to } \\
\text { CNTs ( } 500 \mathrm{~nm} \text { ) of concentrations } 5.0, \\
10.5 \text {, and } 22.05 \mathrm{mg} \mathrm{mL}^{-1} \text { for } 72 \mathrm{~h} \text { in } \\
\text { the presence of surfactant PF } 127\end{array}$ & $\begin{array}{l}\text { Trivial disturbances, including } \\
\text { hyperemia, inflammation, and } \\
\text { aneurysms, were observed in gills. }\end{array}$ & [100] \\
\hline $\mathrm{SiO}_{2} \mathrm{NPs}$ & $\begin{array}{l}\text { Zebrafish (Danio rerio) exposed to } \\
\text { NPs for } 7 \text { days with concentrations of } \\
5 \text { and } 2.5 \mathrm{mg} / \mathrm{L}\end{array}$ & $\begin{array}{l}\text { DNA fragmentation and variation in } \\
\text { antioxidant enzymes were associated } \\
\text { with this sub-lethal dose. }\end{array}$ & [101] \\
\hline
\end{tabular}

Abbreviations: Au: Gold, Ag: Silver, CdS: Cadmium sulphide, GO: Graphene oxide, rGO: reduced graphene oxide, MG: Multi-layer graphene, GNPs: Graphene nanoparticles, $\mathrm{TiO}_{2}$ : Titanium oxide, $\mathrm{ZnO}$ : Zinc oxide, CNTs: Carbon nanotubes, MWCNTs: Multi-walled carbon nanotubes, NOAAs: Nanoobjects, agglomerates, and aggregates, Cu: Copper, UV: Ultraviolet, ROS: Reactive Oxygen Species, $\mathrm{SiO}_{2}$ : Silicon dioxide.

\subsection{Potential Impacts on Air}

Similar to soil and water, NP are likely to be found in the atmosphere in the form of fine dust particles for a prolonged period [102]. Both natural and synthetic NP are present in the atmosphere, but synthetic or engineered NP pose a serious threat due to their smaller size and larger surface area. Rapid urbanization and industrial development have resulted in released waste in the form of volatile organic compounds, suspended airborne particles, and toxic gases (sulfur oxide, ozone, nitrogen oxides and carbon oxides), whereas in urban areas, vehicles are deemed as the key contributor of ENM [103]. The problems associated with polluted air were first noticed by people living in urban areas, but pollution is now a matter of global significance due to its widespread evolution in rural areas [104]. The probable negative impacts of these ENMs on human health, global climate, and urban visibility compel us to control their emissions. ENMs possess diverse chemical compositions and influence the atmospheric chemistry by opening innovative chemical transformation pathways. Similarly, the smaller particles have a greater probability of being suspended in the atmosphere, with a higher residence time, and can easily penetrate or deposit in the respiratory or cardiovascular system [105].

Exposure to aerosolized ENMs at the consumer level can occur through various pathways, including dermal, ingestion, and inhalation. Among these, inhalation is thought to be the most probable entry route into the human body [106]. The aerodynamic diameter of airborne ENMs is responsible for their deposition in the respiratory system [107]. It is a misconception that during production, workers' exposure to ENM is less likely due to controlled environmental conditions. However, it is said that the maximum exposure occurs in the workplace during production, handling, and the use of ENMs [108]. The synthesis method that requires a controlled environment or vacuum is less emissive compared to the method that occurs in ambient air under atmospheric conditions [109].

The inhalation process is more critical in the use of cosmetic powders and sprays, as the emissions occur near the breathing zone and predictably lead to the production of aerosol particles [110]. Based on their probable contact, sprays containing NP were labeled as the most significant class of consumer products [111]. Urban infrastructure such as paint and building tiles, roadside antireflection mirrors, and concrete pavements are also sources of ENM entering the human body via inhalation. The exposure to ENM is also triggered by weather conditions such as rain, ice, and wind. In addition, the release of ENMs into the atmosphere occurs through nanoadditive lubricants in road traffic. Cerium oxide is 
used to enhance fuel efficiency and control the emission of particulate matters. It is said that the morphology and size of cerium oxide can be easily altered during combustion which would affect its fate in the environment [112]. Tire manufacturing also involves the addition of nanocomposites which, upon applying a car's brakes, can be released into the air through erosion. In addition to the above-mentioned processes, the accidental release of ENMs from industries can involve an explosion, fire, and loss of contaminants [113]. However, an air quality expert group in the UK recently reported that none of these emission routes was capable of releasing significant NP concentration into the atmosphere when specifically compared to carbon particles released during combustion [114]. The atmospheric release of ENMs in terms of their concentration and size are governed by various environmental factors such as turbulence, relative humidity, and temperature. Likewise, photochemical reactions initiated by UV radiations and free radicals also facilitate the uprising of atmospheric ENM [63].

In addition to sprays, paints, and tiles, various cleaning products also have ENM in their composition in an indoor environment. They can be easily ingested if deposited on beverages or food, while their presence in dust might pose a serious threat to children. Their presence in an indoor environment might have direct (skin deposition) or indirect contact (surface deposition including furniture) with skin [107]. We are unable to identify a significant concentration of ENM in the air due to limited studies on their quantification and spatial analysis. The health issues triggered by these airborne ENMs are still ambiguous despite health risks associated with black carbon and diesel exhaust having been reported by the World Health Organization (WHO). However, general effects include oxidative stress, coronary heart disease, lipid peroxidation, higher blood pressure, respiratory disease, and cardiovascular disease. The extent of these effects depends upon various factors, including the exposure duration, frequency, and dose. Besides this, human susceptibility linked to lifestyle, sex, age, genetic background, diet, health condition, and family traits also influences the toxic effects of ENM [104].

Conclusively, the existence, detection, and hazardous impacts of the airborne ENMs are still progressing due to limited studies, standard methods, and regulations. However, few studies have addressed workers' exposure to ENMs, while we have been unable to find any study regarding secondary human exposure to materials containing nanomaterials from the air compartment [113].

\section{Removal and Management Strategies}

\subsection{Strategies for Solid Nanowaste}

Landfilling and incineration are common practices for solid nanowaste management. However, they can pose environmental risks and can pollute the soil and groundwater if the waste is not appropriately managed. Thus, recycling is a much better option compared to landfilling and is considered to be a sustainable approach [115]. A recent report said that nanowaste (including nano glass waste, nano rice husk ash, nano silica, and nano metakaolin) incorporated in ultra-high-performance concrete enhances both the concrete bulk resistance and the charge transfer resistance, which delays the corrosion of highstrength steel embedded in concrete [116].

Nanowaste can also be entrapped in a solid matrix binder so that it can be separated easily, or it should be entrapped in an impenetrable vessel to avoid leakage in a soil environment. The detoxification of solid nanowaste is an area of study with no adequate information available. There is a need for extended research to be conducted in this area so that appropriate environment-friendly techniques can be employed for the removal and decontamination of such nanowaste from the environment. There are some suggested disposal methods to deal with chromium dioxide ( $\mathrm{Cr}(\mathrm{IV})$ )-containing nanowaste, which usually results from industrial waste sludge $[117,118]$. In the chlor-alkali and chlorate industries, it was found that magnesium hydroxide $\left(\mathrm{Mg}(\mathrm{OH})_{2}\right) \mathrm{NP}$ formed in wastewater as a result of the brine purification step (of sea salt) [119]. The study showed that converting $\mathrm{Mg}(\mathrm{OH})_{2} \mathrm{NP}$ into bulk resulted in the release of $\mathrm{Cr}(\mathrm{IV})$ in solution (that was previously 
adsorbed). This $\mathrm{Cr}(\mathrm{VI})$-containing solution can be recycled via the chlorate process, whereas the detoxified solids can be reused as additives in other applications, including paints, ceramics, and lubricants. This strategy could pave the way towards solutions for dealing with other nanosized pollutants [118].

Another possible management technique is to change the burning process of the huge amount of solid nanowaste. Incineration is common in various waste treatments facilities, that must be accompanied along the scrubbers for the exhaust gases, to avoid the release of NP into the environment. Various other techniques exist to manage solid waste in such a way that it does not contaminate water bodies or soil. For example, vitrification was used to immobilize wastewater streams, e.g., urban, industrial and nuclear [120]. The success rate of the technique depends on the type and properties of the NP that we want to either dispose of or recycle.

\subsection{Strategies for Liquid Nanowaste}

The use of nanomaterials for water/wastewater treatment is opening new horizons in the field of water treatment technologies. However, the presence of nanomaterials (as nanowaste) in water, either treated or untreated, is significant due to the challenging process of identification, extraction, and removal owing to their physico-chemical properties. Suitable strategies are required to remove nanowaste from the aquatic environment if it exceeds the permissible limit.

Based on recent studies, investigated NP such as $\mathrm{ZnO}, \mathrm{TiO}_{2}$, and $\mathrm{Ag}$ can be $90-95 \%$ eliminated from water, except silica NP due to their surface properties [121]. The NP extracted from water then become part of sewage sludge and required separate treatment. Computer-based simulation models show that treated wastewater is a considerable source of freshwater contamination with nanomaterials [122].

Coagulation coupled with flocculation and sedimentation is a conventional treatment method used to remove nanowaste from water bodies. Few studies have been reported that remove ENMs from water using aluminium $(\mathrm{Al})$ and iron (Fe)-based coagulants [123-125]. Al-based coagulants exhibited higher removal efficiency compared to Fe-based. In these studies, for the removal of $\mathrm{TiO}_{2} \mathrm{NPs}, \mathrm{FeSO}_{4}$ had an advantage over $\mathrm{FeCl}_{3}$ [124], whereas $\mathrm{FeCl}_{3}$ was more effective for the removal of Ag NPs [123]. It has also been said that a single treatment process is not sufficient to remove ENM from water, though the combination of two or more techniques can be effective in this regard. A relatively simple approach, "hand-shaking", showed 100\% efficiency in removing 1D and 2D nanomaterials from water by the emulsification of polluted water with oil. Nanowaste encapsulates in oil and can be easily removed once the oil is separated from water [126]. Studies have been conducted for the removal of ENM from natural and synthetic drinking water using filtration techniques. From these studies, it has been shown that instead of membrane pore size, the stability and size of ENM also plays an important role in its effective removal from membranes [125]. Another study reported the highest removal of $\mathrm{TiO}_{2} \mathrm{NPs}(\sim 99 \%)$ using microfiltration experiments and more than $95 \%$ removal of $\mathrm{Ag}$ NPs and $\mathrm{TiO}_{2} \mathrm{NPs}$ using ultrafiltration. However, for the $\mathrm{ZnO} N$ Ps, the lowest removal was observed due to their dissolution [127].

There is still insufficient knowledge about dealing with nanowaste and how to avoid its adverse effects [8]. Thus, there is an urgent need to work on research techniques to reduce or minimize the release of nanowaste into the environment.

\section{Recommendations}

Nanotechnology can be employed to cope with various problems, but there is a need for more recognition and consciousness in its application and use. Campaigns that increase knowledge and people's awareness can result in a greater understanding and ultimately fewer dangerous situations in the case of interaction with nanomaterials $[6,8]$. Research and funds should be invested to assess current methods and devise new methods to discard and recycle nanomaterials, as well as identify the dangers of using such materials. Most funds are utilized for advancements in new nanomaterials, with less attention focusing on their 
discarding methods. There is an urgent need to work upon and improve current procedures and regulations of nanowaste since nanotechnology is estimated to grow exponentially [2].

Discarding products containing nanomaterials should be handled with caution. Hazardous, toxic, or highly reactive nanowaste should be treated or converted to nontoxic form before disposal. This nanowaste is usually formed during various industrial processes, with a large amount released as a by-product or direct product. Thus, one technique cannot be used to tackle all the different types of nanowaste. Hence, other techniques must be executed to neutralize or reduce the toxic impacts of nanowaste, such as the dissolution of metal oxides in appropriate acid baths for safe disposal and recycling [128]. Keeping in mind the green nanotechnological era, genetically engineered fungi and plants are required to have a high resistance to ENM along with the capability to immobilize nanowaste in waste streams. However, this field of biotreatment remains challenging for researchers in view of the uptake, transfer, and accumulation mechanism.

Before its disposal, the collection of reusable ENM by aggregation followed by shortcircuiting is an efficient waste management strategy. For example, pyrometallurgical and hydrometallurgical pathways can be implemented to retrieve nanomaterials from electronic waste such as batteries [129]. Besides this, a significant amount of ENMs can be recovered from the sewage sludge from wastewater treatment [63].

The recycling of nanowaste is a possible way to separate ENMs from ordinary waste. However, the problem linked to recycling is the differentiation between natural and synthetic or ENMs. Furthermore, the presence of residual dust waste demands precautionary measures to protect both humans and the environment. The most common nanowaste management technique is landfill deposition. However, lack of proper landfill lining is a major obstacle to implementing this technique. Neutralizing and deactivating nanowaste, especially industrial nanowaste, should be performed before discarding to make it nontoxic and non-hazardous. This neutralization can be based on the chemical, thermal, or physical processing of nanotechnology $[130,131]$.

Nanowaste is also incinerated to destroy the flammable parts, while the remaining non-combustible or persistent residual is stored in a chamber awaiting specific attention for its removal. Unfortunately, no specific data are available to investigate the behavior of various nanomaterials in a combustion zone. There is a need to conduct detailed research to determine the specific conditions needed for combustion of the residual ENM to reduce the pollution load. Further research in this area would make incineration an efficient endof-life technique to constrain the hazardous impacts of ENM on human and environmental compartments [132].

Author Contributions: Conceptualization, Z.Z.; methodology, Z.Z.; data curation, S.H., Z.H. and Z.Z.; supervision, Z.Z; writing-original draft preparation, Z.H., Z.Z. and M.S.; investigation, Z.H.; figures, S.H.; writing and proofreading, Z.Z., Z.H. and M.S. All authors have read and agreed to the published version of the manuscript.

Funding: This research received no external funding.

Institutional Review Board Statement: Not applicable.

Informed Consent Statement: Not applicable.

Data Availability Statement: Not applicable.

Acknowledgments: The authors would like to acknowledge Asma Noreen for her help in data curation related to air.

Conflicts of Interest: The authors declare no conflict of interest.

\section{References}

1. Mishra, A.K.; Tiwari, A.; Arya, R.; Panchal, D. Environmental Nanotechnology: Global Framework and Integrative Strategies of Nanowaste Management. In Handbook of Environmental Materials Management; Springer: Cham, Switzerland, 2020; pp. 1-31.

2. Chaturvedi, S.; Dave, P.N. Nanowaste and environmental risk. In Handbook of Advanced Approaches towards Pollution Prevention and Control; Elsevier: Amsterdam, The Netherlands, 2021; pp. 247-260. 
3. Roy, P.; Choudhury, M. Environmental Susceptibility and Nanowaste. In Waste Recycling Technologies for Nanomaterials Manufacturing; Springer: Cham, Switzerland, 2021; pp. 65-87.

4. Sharma, P.; Guleria, P.; Kumar, V. Nanomaterial recycling: An overview. In Nanomaterials Recycling; Elsevier: Amsterdam, The Netherlands, 2022; pp. 3-19.

5. Besha, A.T.; Liu, Y.; Bekele, D.N.; Dong, Z.; Naidu, R.; Gebremariam, G.N. Sustainability and environmental ethics for the application of engineered nanoparticles. Environ. Sci. Policy 2020, 103, 85-98. [CrossRef]

6. Rahman, R.A.; Moamen, O.A.; El-Masry, E. Life Cycle of Polymer Nanocomposites Matrices in Hazardous Waste Treatment. In Handbook of Polymer and Ceramic Nanotechnology; Springer International Publishing: Cham, Switzerland, 2019.

7. Oomen, A.G.; Steinhäuser, K.G.; Bleeker, E.A.; van Broekhuizen, F.; Sips, A.; Dekkers, S.; Wijnhoven, S.W.; Sayre, P.G. Risk assessment frameworks for nanomaterials: Scope, link to regulations, applicability, and outline for future directions in view of needed increase in efficiency. NanoImpact 2018, 9, 1-13. [CrossRef]

8. Boldrin, A.; Hansen, S.F.; Baun, A.; Hartmann, N.I.B.; Astrup, T.F. Environmental exposure assessment framework for nanoparticles in solid waste. J. Nanopart. Res. 2014, 16, 2394. [CrossRef] [PubMed]

9. Marques, B.F.; Cordeiro, L.F.; Kist, L.W.; Bogo, M.R.; López, G.; Pagano, G.; Muratt, D.T.; de Carvalho, L.M.; Külkamp-Guerreiro, I.C.; Monserrat, J.M. Toxicological effects induced by the nanomaterials fullerene and nanosilver in the polychaeta Laeonereis acuta (Nereididae) and in the bacteria communities living at their surface. Mar. Environ. Res. 2013, 89, 53-62. [CrossRef]

10. Giroux, M.S.; Zahra, Z.; Salawu, O.A.; Burgess, R.M.; Ho, K.T.; Adeleye, A.S. Assessing the environmental effects related to quantum dot structure, function, synthesis and exposure. Environ. Sci. Nano. 2022. [CrossRef]

11. Tolaymat, T.; El Badawy, A.; Genaidy, A.; Abdelraheem, W.; Sequeira, R. Analysis of metallic and metal oxide nanomaterial environmental emissions. J. Clean. Prod. 2017, 143, 401-412. [CrossRef]

12. Soni, D.; Naoghare, P.K.; Saravanadevi, S.; Pandey, R.A. Release, transport and toxicity of engineered nanoparticles. In Reviews of Environmental Contamination and Toxicology; Springer: Berlin/Heidelberg, Germany, 2015; pp. 1-47.

13. Rico, C.M.; Majumdar, S.; Duarte-Gardea, M.; Peralta-Videa, J.R.; Gardea-Torresdey, J.L. Interaction of nanoparticles with edible plants and their possible implications in the food chain. J. Agric. Food Chem. 2011, 59, 3485-3498. [CrossRef]

14. Tiede, K.; Boxall, A.B.; Tear, S.P.; Lewis, J.; David, H.; Hassellöv, M. Detection and characterization of engineered nanoparticles in food and the environment. Food Addit. Contam. 2008, 25, 795-821. [CrossRef]

15. McGillicuddy, E.; Murray, I.; Kavanagh, S.; Morrison, L.; Fogarty, A.; Cormican, M.; Dockery, P.; Prendergast, M.; Rowan, N.; Morris, D. Silver nanoparticles in the environment: Sources, detection and ecotoxicology. Sci. Total Environ. 2017, 575, 231-246. [CrossRef]

16. Berube, D.M.; Searson, E.M.; Morton, T.S.; Cummings, C.L. Project on emerging nanotechnologies-consumer product inventory evaluated. Nanotechnol. Law Bus. 2010, 7, 152.

17. Shandilya, N.; Le Bihan, O.; Bressot, C.; Morgeneyer, M. Emission of titanium dioxide nanoparticles from building materials to the environment by wear and weather. Environ. Sci. Technol. 2015, 49, 2163-2170. [CrossRef] [PubMed]

18. Keller, A.A.; McFerran, S.; Lazareva, A.; Suh, S. Global life cycle releases of engineered nanomaterials. J. Nanopart. Res. 2013, 15, 1692. [CrossRef]

19. Mueller, N.C.; Nowack, B. Exposure modeling of engineered nanoparticles in the environment. Environ. Sci. Technol. 2008, 42, 4447-4453. [CrossRef] [PubMed]

20. Li, Q.; Chen, X.; Zhuang, J.; Chen, X. Decontaminating soil organic pollutants with manufactured nanoparticles. Environ. Sci. Pollut. Res. 2016, 23, 11533-11548. [CrossRef]

21. Liu, R.; Lal, R. Potentials of engineered nanoparticles as fertilizers for increasing agronomic productions. Sci. Total Environ. 2015, 514, 131-139. [CrossRef]

22. Kashyap, P.L.; Xiang, X.; Heiden, P. Chitosan nanoparticle based delivery systems for sustainable agriculture. Int. J. Biol. Macromol. 2015, 77, 36-51. [CrossRef]

23. Nowack, B.; Bucheli, T.D. Occurrence, behavior and effects of nanoparticles in the environment. Environ. Pollut. 2007, 150, 5-22 [CrossRef]

24. Kumar, N.; Shah, V.; Walker, V.K. Influence of a nanoparticle mixture on an arctic soil community. Environ. Toxicol. Chem. 2012, 31, 131-135. [CrossRef]

25. Rajput, V.D.; Minkina, T.; Sushkova, S.; Tsitsuashvili, V.; Mandzhieva, S.; Gorovtsov, A.; Nevidomskyaya, D.; Gromakova, N Effect of nanoparticles on crops and soil microbial communities. J. Soils Sediments 2018, 18, 2179-2187. [CrossRef]

26. Rajput, V.D.; Minkina, T.M.; Behal, A.; Sushkova, S.N.; Mandzhieva, S.; Singh, R.; Gorovtsov, A.; Tsitsuashvili, V.S.; Purvis, W.O.; Ghazaryan, K.A. Effects of zinc-oxide nanoparticles on soil, plants, animals and soil organisms: A review. Environ. Nanotechnol. Monit. Manag. 2018, 9, 76-84. [CrossRef]

27. Nowack, B.; David, R.M.; Fissan, H.; Morris, H.; Shatkin, J.A.; Stintz, M.; Zepp, R.; Brouwer, D. Potential release scenarios for carbon nanotubes used in composites. Environ. Int. 2013, 59, 1-11. [CrossRef] [PubMed]

28. Caballero-Guzman, A.; Nowack, B. A critical review of engineered nanomaterial release data: Are current data useful for material flow modeling? Environ. Pollut. 2016, 213, 502-517. [CrossRef] [PubMed]

29. Froggett, S.J.; Clancy, S.F.; Boverhof, D.R.; Canady, R.A. A review and perspective of existing research on the release of nanomaterials from solid nanocomposites. Part. Fibre Toxicol. 2014, 11, 1-28. [CrossRef] 
30. Bystrzejewska-Piotrowska, G.; Golimowski, J.; Urban, P.L. Nanoparticles: Their potential toxicity, waste and environmental management. Waste Manag. 2009, 29, 2587-2595. [CrossRef] [PubMed]

31. Gottschalk, F.; Nowack, B. The release of engineered nanomaterials to the environment. J. Environ. Monit. 2011, 13, 1145-1155. [CrossRef] [PubMed]

32. Smita, S.; Gupta, S.K.; Bartonova, A.; Dusinska, M.; Gutleb, A.C.; Rahman, Q. Nanoparticles in the environment: Assessment using the causal diagram approach. Environ. Health 2012, 11, 1-11. [CrossRef]

33. Ging, J.; Tejerina-Anton, R.; Ramakrishnan, G.; Nielsen, M.; Murphy, K.; Gorham, J.M.; Nguyen, T.; Orlov, A. Development of a conceptual framework for evaluation of nanomaterials release from nanocomposites: Environmental and toxicological implications. Sci. Total Environ. 2014, 473, 9-19. [CrossRef]

34. Yang, Y.; Westerhoff, P. Presence in, and release of, nanomaterials from consumer products. In Nanomaterial; Springer: Dordrecht, The Netherlands, 2014; pp. 1-17.

35. Ding, Y.; Kuhlbusch, T.A.; Van Tongeren, M.; Jiménez, A.S.; Tuinman, I.; Chen, R.; Alvarez, I.L.; Mikolajczyk, U.; Nickel, C.; Meyer, J. Airborne engineered nanomaterials in the workplace-A review of release and worker exposure during nanomaterial production and handling processes. J. Hazard. Mater. 2017, 322, 17-28. [CrossRef]

36. Hansen, S.F.; Michelson, E.S.; Kamper, A.; Borling, P.; Stuer-Lauridsen, F.; Baun, A. Categorization framework to aid exposure assessment of nanomaterials in consumer products. Ecotoxicology 2008, 17, 438-447. [CrossRef]

37. Foss Hansen, S.; Larsen, B.H.; Olsen, S.I.; Baun, A. Categorization framework to aid hazard identification of nanomaterials. Nanotoxicology 2007, 1, 243-250. [CrossRef]

38. Mueller, N.C.; Braun, J.; Bruns, J.; Černík, M.; Rissing, P.; Rickerby, D.; Nowack, B. Application of nanoscale zero valent iron (NZVI) for groundwater remediation in Europe. Environ. Sci. Pollut. Res. 2012, 19, 550-558. [CrossRef] [PubMed]

39. Nowack, B.; Mueller, N.C.; Krug, H.F.; Wick, P. How to consider engineered nanomaterials in major accident regulations? Environ. Sci. Eur. 2014, 26, 2. [CrossRef]

40. Al-Kattan, A.; Wichser, A.; Vonbank, R.; Brunner, S.; Ulrich, A.; Zuin, S.; Arroyo, Y.; Golanski, L.; Nowack, B. Characterization of materials released into water from paint containing nano-SiO 2 . Chemosphere 2015, 119, 1314-1321. [CrossRef] [PubMed]

41. Nowack, B.; Ranville, J.F.; Diamond, S.; Gallego-Urrea, J.A.; Metcalfe, C.; Rose, J.; Horne, N.; Koelmans, A.A.; Klaine, S.J. Potential scenarios for nanomaterial release and subsequent alteration in the environment. Environ. Toxicol. Chem. 2012, 31, 50-59. [CrossRef] [PubMed]

42. Musee, N. Nanowastes and the environment: Potential new waste management paradigm. Environ. Int. 2011, 37, 112-128. [CrossRef]

43. Asmatulu, E.; Twomey, J.; Overcash, M. Life cycle and nano-products: End-of-life assessment. J. Nanopart. Res. 2012, 14, 720. [CrossRef]

44. Bouillard, J.X.; R’Mili, B.; Moranviller, D.; Vignes, A.; Le Bihan, O.; Ustache, A.; Bomfim, J.A.; Frejafon, E.; Fleury, D. Nanosafety by design: Risks from nanocomposite/nanowaste combustion. J. Nanopart. Res. 2013, 15, 1519. [CrossRef]

45. Kotsilkov, S.; Ivanov, E.; Vitanov, N.K. Release of graphene and carbon nanotubes from biodegradable poly (lactic acid) films during degradation and combustion: Risk associated with the end-of-life of nanocomposite food packaging materials. Materials 2018, 11, 2346. [CrossRef]

46. Nyden, M.R.; Harris, R.H.; Kim, Y.S.; Davis, R.D.; Marsh, N.D.; Zammarano, M. Characterizing particle emissions from burning polymer nanocomposites. In Proceedings of the 21th BCC Conference on Flame Retardation; National Institute of Standards and Technology-Nanotech: Gaithersburg, MD, USA, 2010; pp. 717-719.

47. Li, J.; Tong, L.; Fang, Z.; Gu, A.; Xu, Z. Thermal degradation behavior of multi-walled carbon nanotubes/polyamide 6 composites. Polym. Degrad. Stab. 2006, 91, 2046-2052. [CrossRef]

48. Yang, S.; Castilleja, J.R.; Barrera, E.; Lozano, K. Thermal analysis of an acrylonitrile-butadiene-styrene/SWNT composite. Polym. Degrad. Stab. 2004, 83, 383-388. [CrossRef]

49. Dale, A.L.; Casman, E.A.; Lowry, G.V.; Lead, J.R.; Viparelli, E.; Baalousha, M. Modeling nanomaterial environmental fate in aquatic systems. Environ. Sci. Technol. 2015, 49, 2587-2593. [CrossRef] [PubMed]

50. Suresh, A.K.; Pelletier, D.A.; Doktycz, M.J. Relating nanomaterial properties and microbial toxicity. Nanoscale 2013, 5, 463-474. [CrossRef] [PubMed]

51. Cañas, J.E.; Qi, B.; Li, S.; Maul, J.D.; Cox, S.B.; Das, S.; Green, M.J. Acute and reproductive toxicity of nano-sized metal oxides $\left(\mathrm{ZnO}\right.$ and $\left.\mathrm{TiO}_{2}\right)$ to earthworms (Eisenia fetida). J. Environ. Monit. 2011, 13, 3351-3357. [CrossRef]

52. Chai, H.; Yao, J.; Sun, J.; Zhang, C.; Liu, W.; Zhu, M.; Ceccanti, B. The effect of metal oxide nanoparticles on functional bacteria and metabolic profiles in agricultural soil. Bull. Environ. Contam. Toxicol. 2015, 94, 490-495. [CrossRef] [PubMed]

53. Choi, O.; Hu, Z. Size dependent and reactive oxygen species related nanosilver toxicity to nitrifying bacteria. Environ. Sci. Technol. 2008, 42, 4583-4588. [CrossRef]

54. Throbäck, I.N.; Johansson, M.; Rosenquist, M.; Pell, M.; Hansson, M.; Hallin, S. Silver (Ag+) reduces denitrification and induces enrichment of novel nirK genotypes in soil. FEMS Microbiol. Lett. 2007, 270, 189-194. [CrossRef]

55. Peyrot, C.; Wilkinson, K.J.; Desrosiers, M.; Sauvé, S. Effects of silver nanoparticles on soil enzyme activities with and without added organic matter. Environ. Toxicol. Chem. 2014, 33, 115-125. [CrossRef] 
56. Cupi, D.; Hartmann, N.B.; Baun, A. The influence of natural organic matter and aging on suspension stability in guideline toxicity testing of silver, zinc oxide, and titanium dioxide nanoparticles with Daphnia magna. Environ. Toxicol. Chem. 2015, 34, 497-506. [CrossRef]

57. Holden, P.A.; Klaessig, F.; Turco, R.F.; Priester, J.H.; Rico, C.M.; Avila-Arias, H.; Mortimer, M.; Pacpaco, K.; Gardea-Torresdey, J.L. Evaluation of exposure concentrations used in assessing manufactured nanomaterial environmental hazards: Are they relevant? Environ. Sci. Technol. 2014, 48, 10541-10551. [CrossRef]

58. Pachapur, V.L.; Dalila Larios, A.; Cledón, M.; Brar, S.K.; Verma, M.; Surampalli, R.Y. Behavior and characterization of titanium dioxide and silver nanoparticles in soils. Sci. Total Environ. 2016, 563-564, 933-943. [CrossRef]

59. Peralta-Videa, J.R.; Zhao, L.; Lopez-Moreno, M.L.; de la Rosa, G.; Hong, J.; Gardea-Torresdey, J.L. Nanomaterials and the environment: A review for the biennium 2008-2010. J. Hazard. Mater. 2011, 186, 1-15. [CrossRef] [PubMed]

60. Nascimento, M.M.; da Rocha, G.O.; de Andrade, J.B. Pesticides in fine airborne particles: From a green analysis method to atmospheric characterization and risk assessment. Sci. Rep. 2017, 7, 2267.

61. Broomfield, M.; Hansen, S.F.; Pelsy, F. Support for 3rd Regulatory Review on Nanomaterials-Environmental Legislation: Project Report; European Commission: Brussels, Belgium, 2016.

62. Hofman, J.; Staelens, J.; Cordell, R.; Stroobants, C.; Zikova, N.; Hama, S.; Wyche, K.; Kos, G.; Van Der Zee, S.; Smallbone, K. Ultrafine particles in four European urban environments: Results from a new continuous long-term monitoring network. Atmos. Environ. 2016, 136, 68-81. [CrossRef]

63. Abbas, Q.; Yousaf, B.; Ali, M.U.; Munir, M.A.M.; El-Naggar, A.; Rinklebe, J.; Naushad, M. Transformation pathways and fate of engineered nanoparticles (ENPs) in distinct interactive environmental compartments: A review. Environ. Int. 2020, 138, 105646. [CrossRef]

64. Melendres-Sánchez, J.; López-Delgado, R.; Saavedra-Rodríguez, G.; Carrillo-Torres, R.; Sánchez-Zeferino, R.; Ayón, A.; ÁlvarezRamos, M. Zinc sulfide quantum dots coated with PVP: Applications on commercial solar cells. J. Mater. Sci. Mater. 2021, 32, 1457-1465. [CrossRef]

65. Fu, P.P.; Xia, Q.; Hwang, H.-M.; Ray, P.C.; Yu, H. Mechanisms of nanotoxicity: Generation of reactive oxygen species. J. Food Drug Anal. 2014, 22, 64-75. [CrossRef]

66. Aich, N.; Plazas-Tuttle, J.; Lead, J.R.; Saleh, N.B. A critical review of nanohybrids: Synthesis, applications and environmental implications. Environ. Chem. 2014, 11, 609-623. [CrossRef]

67. Savolainen, K. Nanosafety in Europe 2015-2025: Towards Safe and Sustainable Nanomaterials and Nanotechnology Innovations; Finnish Institute of Occupational Health: Helsinki, Finland, 2013.

68. Part, F.; Zecha, G.; Causon, T.; Sinner, E.-K.; Huber-Humer, M. Current limitations and challenges in nanowaste detection, characterisation and monitoring. Waste Manag. 2015, 43, 407-420. [CrossRef]

69. Donia, D.; Carbone, M. Fate of the nanoparticles in environmental cycles. Int. J. Environ. Sci. Technol. 2019, 16, 583-600. [CrossRef]

70. Part, F.; Zaba, C.; Bixner, O.; Zafiu, C.; Lenz, S.; Martetschläger, L.; Hann, S.; Huber-Humer, M.; Ehmoser, E.-K. Mobility and fate of ligand stabilized semiconductor nanoparticles in landfill leachates. J. Hazard. Mater. 2020, 394, 122477. [CrossRef]

71. Mahlalela, L.C.; Ngila, J.C.; Dlamini, L.N. Monitoring the fate and behavior of $\mathrm{TiO}_{2}$ nanoparticles: Simulated in a WWTP with industrial dye-stuff effluent according to OECD 303A. J. Environ. Sci. Health A 2017, 52, 794-803. [CrossRef] [PubMed]

72. Choi, S.; Johnston, M.; Wang, G.-S.; Huang, C. A seasonal observation on the distribution of engineered nanoparticles in municipal wastewater treatment systems exemplified by $\mathrm{TiO}_{2}$ and $\mathrm{ZnO}$. Sci. Total Environ. 2018, 625, 1321-1329. [CrossRef] [PubMed]

73. Arvidsson, R.; Baun, A.; Furberg, A.; Hansen, S.F.; Molander, S. Proxy measures for simplified environmental assessment of manufactured nanomaterials. Environ. Sci. Technol. 2018, 52, 13670-13680. [CrossRef] [PubMed]

74. Durenkamp, M.; Pawlett, M.; Ritz, K.; Harris, J.A.; Neal, A.L.; McGrath, S.P. Nanoparticles within WWTP sludges have minimal impact on leachate quality and soil microbial community structure and function. Environ. Pollut. 2016, 211, 399-405. [CrossRef]

75. Sun, T.Y.; Bornhöft, N.A.; Hungerbühler, K.; Nowack, B. Dynamic probabilistic modeling of environmental emissions of engineered nanomaterials. Environ. Sci. Technol. 2016, 50, 4701-4711. [CrossRef]

76. Alizadeh, S.; Ghoshal, S.; Comeau, Y. Fate and inhibitory effect of silver nanoparticles in high rate moving bed biofilm reactors Sci. Total Environ. 2019, 647, 1199-1210. [CrossRef]

77. Jahan, S.; Yusoff, I.B.; Alias, Y.B.; Bakar, A.F.B.A. Reviews of the toxicity behavior of five potential engineered nanomaterials (ENMs) into the aquatic ecosystem. Toxicol. Rep. 2017, 4, 211-220. [CrossRef]

78. Peters, R.J.; van Bemmel, G.; Milani, N.B.; den Hertog, G.C.; Undas, A.K.; van der Lee, M.; Bouwmeester, H. Detection of nanoparticles in Dutch surface waters. Sci. Total Environ. 2018, 621, 210-218. [CrossRef]

79. Missaoui, W.N.; Arnold, R.D.; Cummings, B.S. Toxicological status of nanoparticles: What we know and what we don't know. Chem. Biol. Interact. 2018, 295, 1-12. [CrossRef]

80. Prajitha, N.; Athira, S.; Mohanan, P. Bio-interactions and risks of engineered nanoparticles. Environ. Res. 2019, 172, 98-108. [CrossRef]

81. Zhu, X.; Chang, Y.; Chen, Y. Toxicity and bioaccumulation of $\mathrm{TiO}_{2}$ nanoparticle aggregates in Daphnia magna. Chemosphere 2010, 78, 209-215. [CrossRef] [PubMed]

82. Bacchetta, R.; Maran, B.; Marelli, M.; Santo, N.; Tremolada, P. Role of soluble zinc in ZnO nanoparticle cytotoxicity in Daphnia magna: A morphological approach. Environ. Res. 2016, 148, 376-385. [CrossRef] [PubMed] 
83. Chen, Q.; Hu, X.; Wang, R.; Yuan, J.; Yin, D. Fullerene inhibits benzo (a) pyrene Efflux from Cyprinus carpio hepatocytes by affecting cell membrane fluidity and P-glycoprotein expression. Aquat. Toxicol. 2016, 174, 36-45. [CrossRef] [PubMed]

84. Spengler, A.; Wanninger, L.; Pflugmacher, S. Oxidative stress mediated toxicity of $\mathrm{TiO}_{2}$ nanoparticles after a concentration and time dependent exposure of the aquatic macrophyte Hydrilla verticillata. Aquat. Toxicol. 2017, 190, 32-39. [CrossRef]

85. Schiavo, S.; Oliviero, M.; Miglietta, M.; Rametta, G.; Manzo, S. Genotoxic and cytotoxic effects of ZnO nanoparticles for Dunaliella tertiolecta and comparison with $\mathrm{SiO}_{2}$ and $\mathrm{TiO}_{2}$ effects at population growth inhibition levels. Sci. Total Environ. 2016, 550, 619-627. [CrossRef]

86. Verma, Y.; Rani, V.; Rana, S.V.S. Assessment of cadmium sulphide nanoparticles toxicity in the gills of a fresh water fish. Environ. Nanotechnol. Monit. Manag. 2020, 13, 100280. [CrossRef]

87. Saxena, P. Toxicity assessment of $\mathrm{ZnO}$ nanoparticles to freshwater microalgae Coelastrella terrestris. Environ. Sci. Pollut. Res. 2019, 26, 26991-27001. [CrossRef]

88. Wu, D.; Yang, S.; Du, W.; Yin, Y.; Zhang, J.; Guo, H. Effects of titanium dioxide nanoparticles on Microcystis aeruginosa and microcystins production and release. J. Hazard. Mater. 2019, 377, 1-7. [CrossRef]

89. Xia, B.; Sui, Q.; Sun, X.; Han, Q.; Chen, B.; Zhu, L.; Qu, K. Ocean acidification increases the toxic effects of $\mathrm{TiO}_{2}$ nanoparticles on the marine microalga Chlorella vulgaris. J. Hazard. Mater. 2018, 346, 1-9. [CrossRef]

90. Hu, J.; Wang, J.; Liu, S.; Zhang, Z.; Zhang, H.; Cai, X.; Pan, J.; Liu, J. Effect of $\mathrm{TiO}_{2}$ nanoparticle aggregation on marine microalgae Isochrysis galbana. J. Environ. Sci. 2018, 66, 208-215. [CrossRef]

91. Movafeghi, A.; Khataee, A.; Abedi, M.; Tarrahi, R.; Dadpour, M.; Vafaei, F. Effects of $\mathrm{TiO}_{2}$ nanoparticles on the aquatic plant Spirodela polyrrhiza: Evaluation of growth parameters, pigment contents and antioxidant enzyme activities. J. Environ. Sci. 2018, 64, 130-138. [CrossRef] [PubMed]

92. Zhao, J.; Cao, X.; Wang, Z.; Dai, Y.; Xing, B. Mechanistic understanding toward the toxicity of graphene-family materials to freshwater algae. Water Res. 2017, 111, 18-27. [CrossRef] [PubMed]

93. Zhao, X.; Ren, X.; Zhu, R.; Luo, Z.; Ren, B. Zinc oxide nanoparticles induce oxidative DNA damage and ROS-triggered mitochondria-mediated apoptosis in zebrafish embryos. Aquat. Toxicol. 2016, 180, 56-70. [CrossRef] [PubMed]

94. Bruneau, A.; Turcotte, P.; Pilote, M.; Gagné, F.; Gagnon, C. Fate of silver nanoparticles in wastewater and immunotoxic effects on rainbow trout. Aquat. Toxicol. 2016, 174, 70-81. [CrossRef]

95. Sharma, N.; Rather, M.A.; Ajima, M.N.; Gireesh-Babu, P.; Kumar, K.; Sharma, R. Assessment of DNA damage and molecular responses in Labeo rohita (Hamilton, 1822) following short-term exposure to silver nanoparticles. Food Chem. Toxicol. 2016, 96, 122-132. [CrossRef]

96. Boran, H.; Ulutas, G. Genotoxic effects and gene expression changes in larval zebrafish after exposure to $\mathrm{ZnCl}_{2}$ and $\mathrm{ZnO}$ nanoparticles. Dis. Aquat. Org. 2016, 117, 205-214. [CrossRef]

97. Vignardi, C.P.; Hasue, F.M.; Sartório, P.V.; Cardoso, C.M.; Machado, A.S.; Passos, M.J.; Santos, T.C.; Nucci, J.M.; Hewer, T.L.; Watanabe, I.-S. Genotoxicity, potential cytotoxicity and cell uptake of titanium dioxide nanoparticles in the marine fish Trachinotus carolinus (Linnaeus, 1766). Aquat. Toxicol. 2015, 158, 218-229. [CrossRef]

98. Dedeh, A.; Ciutat, A.; Treguer-Delapierre, M.; Bourdineaud, J.-P. Impact of gold nanoparticles on zebrafish exposed to a spiked sediment. Nanotoxicology 2015, 9, 71-80. [CrossRef]

99. Kim, M.-S.; Louis, K.; Pedersen, J.; Hamers, R.; Peterson, R.; Heideman, W. Using citrate-functionalized $\mathrm{TiO}_{2}$ nanoparticles to study the effect of particle size on zebrafish embryo toxicity. Analyst 2014, 139, 964-972. [CrossRef]

100. De Souza Filho, J.; Matsubara, E.Y.; Franchi, L.P.; Martins, I.P.; Rivera, L.M.R.; Rosolen, J.M.; Grisolia, C.K. Evaluation of carbon nanotubes network toxicity in zebrafish (Danio rerio) model. Environ. Res. 2014, 134, 9-16. [CrossRef]

101. Ramesh, R.; Kavitha, P.; Kanipandian, N.; Arun, S.; Thirumurugan, R.; Subramanian, P. Alteration of antioxidant enzymes and impairment of DNA in the $\mathrm{SiO}_{2}$ nanoparticles exposed zebra fish (Danio rerio). Environ. Monit. Asses. 2013, 185, 5873-5881. [CrossRef] [PubMed]

102. Ermolin, M.S.; Fedotov, P.S.; Malik, N.A.; Karandashev, V.K. Nanoparticles of volcanic ash as a carrier for toxic elements on the global scale. Chemosphere 2018, 200, 16-22. [CrossRef] [PubMed]

103. Baalousha, M.; Yang, Y.; Vance, M.E.; Colman, B.P.; McNeal, S.; Xu, J.; Blaszczak, J.; Steele, M.; Bernhardt, E.; Hochella, M.F., Jr. Outdoor urban nanomaterials: The emergence of a new, integrated, and critical field of study. Sci. Total Environ. 2016, 557, 740-753. [CrossRef] [PubMed]

104. Enyoh, C.E.; Verla, A.W.; Qingyue, W.; Ohiagu, F.O.; Chowdhury, A.H.; Enyoh, E.C.; Chowdhury, T.; Verla, E.N.; Chinwendu, U.P. An overview of emerging pollutants in air: Method of analysis and potential public health concern from human environmental exposure. Trends Environ. Anal. Chem. 2020, 28, e00107. [CrossRef]

105. Kumar, P.; Robins, A.; Vardoulakis, S.; Britter, R. A review of the characteristics of nanoparticles in the urban atmosphere and the prospects for developing regulatory controls. Atmos. Environ. 2010, 44, 5035-5052. [CrossRef]

106. Biskos, G.; Schmidt-Ott, A. Airborne engineered nanoparticles: Potential risks and monitoring challenges for assessing their impacts on children. Paediatr. Respir. Rev. 2012, 13, 79-83. [CrossRef]

107. Vance, M.E.; Marr, L.C. Exposure to airborne engineered nanoparticles in the indoor environment. Atmos. Environ. 2015, 106, 503-509. [CrossRef]

108. Asbach, C. Exposure Measurement at Workplaces. In Nanoengineering, Global Approaches to Health and Safety Issues; Dolez, P.I., Ed.; Elsevier: Amsterdam, The Netherlands, 2015. 
109. John, A.C.; Küpper, M.; Manders-Groot, A.M.; Debray, B.; Lacome, J.-M.; Kuhlbusch, T.A. Emissions and possible environmental implication of engineered nanomaterials (ENMs) in the atmosphere. Atmosphere 2017, 8, 84. [CrossRef]

110. Calderón, L.; Han, T.T.; McGilvery, C.M.; Yang, L.; Subramaniam, P.; Lee, K.-B.; Schwander, S.; Tetley, T.D.; Georgopoulos, P.G.; Ryan, M. Release of airborne particles and Ag and Zn compounds from nanotechnology-enabled consumer sprays: Implications for inhalation exposure. Atmos. Environ. 2017, 155, 85-96. [CrossRef]

111. Losert, S.; von Goetz, N.; Bekker, C.; Fransman, W.; Wijnhoven, S.W.; Delmaar, C.; Hungerbuhler, K.; Ulrich, A. Human Exposure to Conventional and Nanoparticle-Containing Sprays: A Critical Review. Environ. Sci. Technol. 2014, 48, 5366-5378. [CrossRef]

112. Dale, J.G.; Cox, S.S.; Vance, M.E.; Marr, L.C.; Hochella, M.F., Jr. Transformation of cerium oxide nanoparticles from a diesel fuel additive during combustion in a diesel engine. Environ. Sci. Technol. 2017, 51, 1973-1980. [CrossRef] [PubMed]

113. Sánchez, M.B.; Fito-López, C.; Cajaraville, M. A life cycle perspective of the exposure to airborne nanoparticles released from nanotechnology enabled products and applications. In Health and Environmental Safety of Nanomaterials; Elsevier: Amsterdam, The Netherlands, 2021; pp. 173-194.

114. Cadotte, M.W.; Bader, E.; Chamberlain, B.; Goddard, M.A.; MacIvor, J.S.; Ki, T. Nature-based solutions and the built environment. In Nature-Based Solutions for Climate Change in the UK; British Ecological Society: London, UK, 2021; p. 121.

115. Behera, A.; Sahini, D.; Pardhi, D. Procedures for recycling of nanomaterials: A sustainable approach. In Nanomaterials Recycling; Elsevier: Amsterdam, The Netherlands, 2022; pp. 175-207.

116. Mostafa, S.A.; El-Deeb, M.M.; Farghali, A.A.; Faried, A.S. Evaluation of the nano silica and nano waste materials on the corrosion protection of high strength steel embedded in ultra-high performance concrete. Sci. Rep. 2021, 11, 1-16. [CrossRef] [PubMed]

117. Liu, W.; Huang, F.; Liao, Y.; Zhang, J.; Ren, G.; Zhuang, Z.; Zhen, J.; Lin, Z.; Wang, C. Treatment of CrVI-Containing Mg(OH) 2 Nanowaste. Angew. Chem. 2008, 120, 5701-5704. [CrossRef]

118. Liu, W.; Xu, X.; Wang, Y.; He, Z.; Zhuo, N.; Huang, F.; Lin, Z. Treatment of Cr (VI)-containing nanowastes via the growth of nanomaterial. Chin. Sci. Bull. 2010, 55, 373-377. [CrossRef]

119. Chupa, J.; Misner, S.; Sachdev, A.; Wisniewski, P.; Smith, G.A. Soap, fatty acids, and synthetic detergents. In Handbook of Industrial Chemistry and Biotechnology; Springer: Berlin/Heidelberg, Germany, 2012; pp. 1431-1471.

120. Kavouras, P.; Komninou, P.; Chrissafis, K.; Kaimakamis, G.; Kokkou, S.; Paraskevopoulos, K.; Karakostas, T. Microstructural changes of processed vitrified solid waste products. J. Eur. Ceram. Soc. 2003, 23, 1305-1311. [CrossRef]

121. Wu, J.; Zhu, G.; Yu, R. Fates and impacts of nanomaterial contaminants in biological wastewater treatment system: A review. Water Air Soil Pollut. 2018, 229, 1-21. [CrossRef]

122. Sun, T.Y.; Gottschalk, F.; Hungerbühler, K.; Nowack, B. Comprehensive probabilistic modelling of environmental emissions of engineered nanomaterials. Environ. Pollut. 2014, 185, 69-76. [CrossRef]

123. Sun, Q.; Li, Y.; Tang, T.; Yuan, Z.; Yu, C.-P. Removal of silver nanoparticles by coagulation processes. J. Hazard. Mater. 2013, 261, 414-420. [CrossRef]

124. Honda, R.J.; Keene, V.; Daniels, L.; Walker, S.L. Removal of $\mathrm{TiO}_{2}$ nanoparticles during primary water treatment: Role of coagulant type, dose, and nanoparticle concentration. Environ. Eng. Sci. 2014, 31, 127-134. [CrossRef]

125. Sousa, V.S.; Teixeira, M.R. Metal-based engineered nanoparticles in the drinking water treatment systems: A critical review. Sci. Total Environ. 2020, 707, 136077. [CrossRef]

126. Lee, C.H.; Johnson, N.; Drelich, J.; Yap, Y.K. The performance of superhydrophobic and superoleophilic carbon nanotube meshes in water-oil filtration. Carbon 2011, 49, 669-676. [CrossRef]

127. Chalew, T.E.A.; Ajmani, G.S.; Huang, H.; Schwab, K.J. Evaluating nanoparticle breakthrough during drinking water treatment. Environ. Health Perspect. 2013, 121, 1161-1166. [CrossRef] [PubMed]

128. Younis, S.A.; El-Fawal, E.M.; Serp, P. Nano-wastes and the environment: Potential challenges and opportunities of nano-waste management paradigm for greener nanotechnologies. In Handbook of Environmental Materials Management; Springer: Cham, Switzerland, 2018; pp. 1-72.

129. Dutta, T.; Kim, K.-H.; Deep, A.; Szulejko, J.E.; Vellingiri, K.; Kumar, S.; Kwon, E.E.; Yun, S.-T. Recovery of nanomaterials from battery and electronic wastes: A new paradigm of environmental waste management. Renew. Sust. Energ. Rev. 2018, 82, 3694-3704. [CrossRef]

130. Gajewicz, A.; Rasulev, B.; Dinadayalane, T.C.; Urbaszek, P.; Puzyn, T.; Leszczynska, D.; Leszczynski, J. Advancing risk assessment of engineered nanomaterials: Application of computational approaches. Adv. Drug Deliv. Rev. 2012, 64, 1663-1693. [CrossRef]

131. Gambardella, C.; Gallus, L.; Gatti, A.M.; Faimali, M.; Carbone, S.; Antisari, L.V.; Falugi, C.; Ferrando, S. Toxicity and transfer of metal oxide nanoparticles from microalgae to sea urchin larvae. Chem. Ecol. 2014, 30, 308-316. [CrossRef]

132. Holder, A.L.; Vejerano, E.P.; Zhou, X.; Marr, L.C. Nanomaterial disposal by incineration. Environ. Sci. Process. Impacts 2013, 15, 1652-1664. [CrossRef] 